\title{
RELATIONSHIP OF TRAINING AND MOTIVATION WITH TEACHERS' PERFORMANCE: A CASE OF PUBLIC AND PRIVATE SCHOOLS OF SOUTHREN PUNJAB
}

\author{
Lubna Jabeen ${ }^{1, a,}$ Sajid Iqbal ${ }^{2, b}$ \\ ${ }^{1}$ Scholar Social Sciences School Indus International Institute DG-Khan \\ ${ }^{2}$ Head of Management \& Social Sciences School Indus International Institute DG-Khan \\ aE-mail address:talhssaif22@gmail.com, ${ }^{b}$ E-mail address:sajid.edu@outlook.com
}

Keywords: Training, Motivation, Job Performance, Correlation, Regression, Sample

\begin{abstract}
The current study aims to investigate the relation of training and motivation with job performance and study has used connivance sampling technique to acquire the data. Where the population of the study contains on the southern Punjab schools and sample of the study contains on the DG-Khan schools teachers. Thus, correlation analysis, regression analysis are applied at the study. And the results showed the significant relation of training, insignificant relationship of motivation with job performance.
\end{abstract}

\section{INTRODUCTION}

Teachers play a vital role in teaching learning process. According to the Government of Pakistan (1970) teachers are the strength of the nation because teachers are the nation builder. So in order to produce strong nation, teachers must be competent enough because only then they will be able to produce competent future professionalists. Teachers become competent through trainings, professional development courses and extrinsic or intrinsic motivation.

Training is the process of improving and increasing the capabilities of staff. Teachers' professional development is important because students deserve the best.

Ongoing professional development keeps teachers up to date on new research and changes in education, new advancement in teaching learning process, new curriculum resources and emerging technology tools for the classrooms. Teachers can enhance their professional development by attending different workshops, conferences, online courses, seminars and training courses. It is usually assumed that training leads to increase performance.

Trainings make the teachers capable to meet the everyday challenges in the field of education, to make their teaching process effective and to increase their competency and performance in this field.

Motivation has also the positive impact on increasing the performance of teachers.

Motivation of teachers is very important because it directly affects the students. Teachers are motivated by intrinsic and extrinsic factors.

The aim of the current study is to find out the relationship of trainings and motivation on teachers' performance and competency.

The specific objectives of the current study are to find out the effectiveness of trainings and relationship of trainings and motivation with teachers' competency.

The current study is important in its nature although it is widely investigated yet it is less investigated in Asian context specifically in Pakistani region D.G.Khan. The current study is very significant because it will provide help to administrators and teachers to make their performance best in the field of education in order to meet the advance requirements of this field.

Scheme of this paper consists of five parts. First part contains introduction, second part explains review of literature, third part elaborates methodology, fourth part describes result and analysis and fifth part explains findings. 


\section{LITERATURE REVIEW}

Harlod Wenglinskyn (2002) found that professional development seems to influence teachers' classroom practices strongly. It was suggested that schools tend to choose between hiring more teachers with better pre service training and providing teachers with more and better inservice training.

Dr. Muhammad Tayyab Alam, Ms. Sabeen Farid (2011) concluded that low salaries of the teachers affected their teaching, so teachers must be motivated by giving handsome salary packages and other incentives. It was recommended that teachers should get teacher training, should be given due respect and should be paid according to their qualifications and abilities.

Linda Darling-Hammond (2000) suggested after using data from a 50-state survey of policies, state case study analyses, the 1993-94 Schools and Staffing Surveys (SASS), and the National Assessment of Educational Progress (NAEP) that quality and competency of teachers is related to improvement in students' performance. This analysis suggests that policies adopted by states regarding teacher education, licensing, hiring, and professional development may make an important difference in the qualifications and capacities that teachers bring to their work.

Muhammad Amin , Rahmat ullah Shah, Muhammad Ayaz (2013) collected information from 400 teachers of 40 Secondary Schools of Khyber Pakhtunkhwa and found that job performance level of teachers was above average because they use different teaching methods and attended training sessions to enhance their teaching performance.

Graham Gibbs, Martin Coffey (2004) reported a study on the effectiveness of university teachers' training involving 22 universities in 8 countries. A training group of teachers and their students were studied at the start of their training and one year later. A control group of new teachers received no training and both they and their students were studied in the same way and found an evidence of a range of positive changes in teachers in the training group, and in their students, and a contrasting lack of change, or negative changes, in untrained teachers from the control group.

Cristina-Corina Bentea, Valerica Anghelache (2012) conducted study from 122 Romanian teachers of primary, secondary and high schools about teachers' motivation and job satisfaction varying with the gender and found no differences between men and women in overall job satisfaction and its dimensions, but satisfaction is affected by the level of continuous training. Thus, hypothesis of the study are as follows,

H1: There is significant positive relationship of training and job performance

H2: there is significant positive relationship of motivation and job performance.

\section{METHODOLOGY OF STUDY}

The current study is exploratory in nature and explores the relationship of training and motivation with job performance. The study population consists of southern Punjab school teachers specifically allied school teachers and the sample of the study consists of the DG-Khan allied schools teachers. The total number of the respondents consists of 50 where 30 are as female and 20 are as male with respect to their gender specification. The study has acquired the data through primary source by using questionnaire. The scale is adopted from Aziz, (2012) and Amin, (2013) respectively. The scale of the study is05 point likert scale.. While, the total questions of the scale were 24 regarding motivation and training

\section{RESULTS \& ANALYSIS}

Table 01

Correlation Analysis

\begin{tabular}{llll}
\hline Variables & Motivation & Performance & Training \\
\hline Motivation & 1 & & \\
Performance & $.520^{* *}$ & 1 & 1 \\
Trainings & $.639^{* *}$ & $.599 * *$ & 1 \\
\hline
\end{tabular}


The table 1 explains the results of the correlation analysis where the motivation is significantly correlated with performance at $\mathrm{p}<0.05$. Moreover, performance is significantly correlated with $0.520^{* *} \mathrm{p}<(0.05)$. And training is significantly correlated with $\left.0.639^{* *} \mathrm{p}<0.05\right)$.

Table 02

Model Summery

\begin{tabular}{llllll}
\hline Model & $\mathrm{R}$ & R Square & Ad.R.Sq & Error Est. & DW \\
\hline 1 & .625 & .390 & .365 & .368 & 1.903 \\
\hline
\end{tabular}

In model summery table 02 explains the $\mathrm{R}$ as 0.625 , and adjusted $\mathrm{r}$ square as 0.365 . While, the durbin Watson value is 1.903 that is less than 02 .

Table 03

Regression Analysis

\begin{tabular}{llll}
\hline Variables & Beta & t-statistics & Significance \\
\hline Constant & .469 & 2.074 & .044 \\
Motivation & .184 & 1.568 & .124 \\
Training & .595 & 3.040 & .004 \\
\hline
\end{tabular}

The table three results explain the regression analysis of the study where constant value of beta is $.469, \mathrm{t}$ stats is 2.074 and significance value is .044 . moreover, the motivation has value of beta as $.184, \mathrm{t}$ stats as 1.568 and $\mathrm{p}$ value is 0.124 greater than 0.05 . Whereas training is 0.595 percent represented by beta and is significant with 0.004 where $p$ value is less than 0.05 .

\section{CONCLUSION}

The current study aimed to investigate the relationship of training and motivation on job performance. Thus, the study revealed significant relationship of the training with job performance and insignificant relationship of the motivation with job performance. Thus, the hypothesis of motivation with job performance is rejected. And the study concluded that various motivational techniques should adopted by schools management to enhance personal performance as well i-e compensation plans, duty timing hours, work load Burdon, social benefits. Hence, the study revealed its findings regarding training with past investigations and regarding motivation has contradicted as well.

\section{References}

[1] Wenglinsky, H. (2002, February 13). How schools matter: The link between teacher classroom practices and student academic performance, Education Policy Analysis Archives, vol.10 (12).

[2] Aslam. T, Farid. S.(2011). Factors Affecting Teachers Motivation, International Journal of Business and Social Science, Vol. 2 No. 1

[3] Hammond. L. (2000). Teacher Quality and Student Achievement: A Review of State Policy Evidence, EDUCATION POLICY ANALYSIS ARCHIVES, Volume 8 Number 1

[4] Amin et. al., (2013) . Teacher's Job Performance. Gomal University Journal of Research, vol. 29(2)

[5] Gibbs. G, Coffey.M (2004). The Impact Of Training Of University Teachers on their Teaching Skills, their Approach to Teaching and the Approach to Learning of their Students, $A$ CTIVE LEARNING IN HIGHER EDUCATION, vol.5(1)

[6] Bentea. C, Anghelache. V.(2012). Teachers' motivation and satisfaction for professional activity, Procedia - Social and Behavioral Science, vol. (33) 